\title{
FAKTOR-FAKTOR YANG MEMPENGARUHI RETURN SAHAM PADA PERUSAHAAN SUB SEKTOR KOSMETIK DAN KEPERLUAN RUMAH TANGGA YANG TERDAFTAR DI BURSA EFEK INDONESIA
}

\author{
Oleh: \\ Zulfikar Ramadhan ${ }^{1}$ \\ Dhea Aulia ${ }^{2}$ \\ ${ }^{1), 2)}$ Fakultas Ekonomi dan Bisnis \\ Universitas Muhammadiyah Jakarta \\ Email: \\ zulfikar.ramadhan@umj.ac.id
}

\begin{abstract}
ABSTRAK
Tujuan penelitian ini adalah untuk mengetahui pengaruh economic value added, return on equity, dan earning per share terhadap return saham. Penelitian ini menggunakan metode pendekatan kuantitatif dan jenis penelitian asosiatif. Sumber data yang digunakan adalah data sekunder. Populasi yang digunakan adalah perusahaan sub sektor kosmetik dan keperluan rumah tangga yang terdaftar di Bursa Efek Indonesia. Teknik pengambilan sampel menggunakan metode purposive sampling. Teknik analisis data yang digunakan adalah analisis regresi data panel menggunakan Eviews 10. Hasil penelitian ini menunjukkan bahwa economic value added berpengaruh negatif dan tidak signifikan terhadap return saham. Sedangkan return on equity dan earning per share berpengaruh positif dan tidak signifikan terhadap return saham.
\end{abstract}

Kata kunci: economic value added, earning per share, return on equity, dan return saham. 


\begin{abstract}
The purpose of this study was to determine the effect of economic value-added, return on equity, and earnings per share on stock returns. This study uses a quantitative approach and associative research. The data source used is secondary data. The population used is the cosmetics sub-sector and household needs companies listed on the Indonesia Stock Exchange. The sampling technique uses purposive sampling method. The data analysis technique used is panel data regression analysis using Eviews 10. The results of this study indicate that the economic value added has a negative and not significant effect on stock returns. While return on equity and earnings per share have a positive and not significant effect on stock returns.
\end{abstract}

Keywords: economic value added, return on equity, earnings per share and stock returns.

\title{
A. PENDAHULUAN
}

Nilai tukar rupiah yang bergerak melemah hingga menembus Rp 14.920 per dolar AS berpotensi menaikkan harga sejumlah barang. Kenaikan harga terutama terjadi pada produk yang diimpor maupun yang menggunakan bahan baku impor (Agusyanti, 2018). Perkiraan barang-barang yang mengalami kenaikan harga bahan baku salah satunya adalah produk kosmetik. Akibatnya produk kosmetik pun mengalami kenaikan harga. Kenaikan harga tersebut berdampak kepada pelemahan daya tarik konsumen terhadap pembelian produk kosmetik. Produsen kosmetika dan jamu tradisional (Rahmawati, 2018). Kerugian yang dialami berakibat terhadap laba yang dihasilkan dan berkaitan pula dengan harga saham perusahaan kosmetik yang diperjual belikan di Bursa Efek Indonesia. Penurunan harga saham dirasakan oleh PT Mustika Ratu Tbk (MRAT) yang turun sebesar 1,9\% ke level 206 pada perdagangan terakhir tahun 2017. Penurunan saham juga dialami oleh PT Martina Berto Tbk (MBTO), yang turun sebesar 27,01\% ke level 135 pada perdagangan hari terakhir tahun 2017. Penurunan harga saham yang dialami perusahaan kosmetik tersebut mempengaruhi return saham yang dihasilkan. Fenomena turunnya harga saham mengindikasikan bahwa return saham yang diperoleh investor dari perusahaan tersebut belum optimal. Artinya, realisasi return saham belum sesuai dengan return yang diharapkan oleh investor.

Banyak faktor yang mempengaruhi return saham, diantaranya adalah informasi yang bersifat fundamental maupun teknikal (Sudarsono \& Sudiyatno, 2016). Faktor fundamental adalah faktor-faktor yang berasal dari dalam perusahaan yang mengeluarkan saham itu sendiri (emiten). Apabila perusahaan yang mengeluarkan saham dalam kondisi yang baik kinerjanya, harga saham akan cenderung meningkat dan apabila harga saham meningkat maka return yang diterima juga meningkat. Hal ini di sebabkan kepercayaan investor kepada emiten semakin baik, investor mempunyai harapan akan memperoleh bagian keuntungan atau dividen yang besar. Faktor-faktor yang mempengaruhi return saham dalam 
penelitian ini adalah economic value added, return on equity, dan earning per share.

Terdapat fenomena yang terjadi antara penelitian-penelitian sebelumnya mengenai faktor-faktor yang mempengaruhi return saham, dimana hasil penelitian tersebut masih belum menemukan hasil yang konsisten. Seperti halnya pada perbedaan hasil penelitian pengaruh economic value added terhadap return saham. Penelitian yang dilakukan oleh (Hidajat, 2018), (Montoliang \& Tjun, 2018) dan (Awan, Siddique, \& Sarwar, 2014) menunjukkan hasil pengaruh yang signifikan antara economic value added terhadap return saham, sedangkan penelitian yang dilakukan oleh (Sudiyatno \& Suharmanto, 2011), (Sasongko \& Shaliza, 2018) menunjukkan pengaruh yang tidak signifikan antara economic value added terhadap return saham.

Selanjutnya perbedaan penelitian pengaruh return on equity terhadap return saham, terlihat pada penelitian yang dilakukan oleh (Himmatussuhra, Mardani, \& ABS, 2018), (Hidajat, 2018), (Sudiyatno \& Suharmanto, 2011), dan (Saragih, 2018) yang menunjukkan pengaruh yang signifikan antara return on equity terhadap return saham, sementara penelitian yang dilakukan (Legiman, Tommy, \& Untu, 2015), (Sasongko \& Shaliza, 2018), (Aisah \& Mandala, 2016) menunjukkan pengaruh yang tidak signifikan antara return on equity terhadap return saham. Dan mengenai perbedaan penelitian pengaruh earning per share terhadap return saham. dari penelitian yang dilakukan oleh (Hidajat, 2018) dan (Atidhira \& Yustina, 2017) yang menunjukkan pengaruh yang signifikan antara earning per share terhadap return saham, sementara penelitian yang dilakukan oleh Himmatussuhra, dkk (2018), Arista (2012), Aisah dan Mandala (2016) menunjukkan pengaruh yang tidak signifikan antara earning per share terhadap return saham.

Berdasarkan fenomena dan latar belakang, maka tujuan dari penelitian ini adalah untuk mengetahui pengaruh economic value added, return on equity dan earning per share terhadap return saham pada perusahaan sub sektor kosmetik dan keperluan rumah tangga yang terdaftar di Bursa Efek Indonesia.

\section{B. KAJIAN PUSTAKA}

\section{Return Saham}

Hartono dalam (Hartono, 2015) menyatakan bahwa return merupakan hasil yang diperoleh dari investasi. Return dapat berupa return realisasi yang sudah terjadi atau return ekspektasi yang belum terjadi tetapi yang diharapkan akan terjadi di masa mendatang. Sedangkan (Arista, 2012) mengungkapkan bahwa return saham merupakan harga jual saham diatas harga belinya. Semakin tinggi harga jual saham di atas harga belinya, maka semakin tinggi pula return yang diperoleh investor. Apabila seorang investor menginginkan return yang tinggi maka ia harus bersedia menanggung risiko yang lebih tinggi, demikian pula sebaiknya bila menginginkan return rendah maka risiko yang akan ditanggung juga rendah.

Komponen return saham terdiri dari dua komponen utama yaitu yield dan capital gain (loss). Jika investor membeli saham, yield ditunjukkan oleh besarnya 
dividen sedangkan capital gain merupakan kenaikan (penurunan) harga suatu saham yang bisa memberikan keuntungan (kerugian) bagi investor. Fluktuasi harga saham yang tinggi dan dividen yang tidak selalu dibayarkan oleh emiten menyebabkan adanya fluktuasi return atas saham. Fluktuasi return yang tinggi membawa risiko yang tinggi bagi investor. Investor juga tidak dapat secara pasti mengetahui risiko apa yang akan diterimanya dalam melakukan suatu investasi (Tandelilin, 2010).

\section{Economic Value Added}

Economic Value Added adalah ukuran laba yang sesungguhnya dari suatu perusahaan dalam tahun berjalan, nilai EVA menunjukkan sisa laba yang sebenarnya setelah laba bersih perusahaan dikurangi dengan seluruh biaya modal termasuk biaya ekuitas (Kusuma \& Topowijono, 2018). Prinsip EVA adalah memberikan sistem pengukuran yang baik untuk menilai suatu kinerja dan prestasi keuangan manajemen perusahaan karena EVA berhubungan langsung dengan nilai pasar suatu perusahaan. Sama seperti halnya profitabilitas, tinggi rendahnya EVA tidak akan mempengaruhi investor dalam mempengaruhi keputusannya (Sasongko \& Shaliza, 2018).

\section{Return On Equity}

Return on equity adalah rasio ini mengukur kemampuan menghasilkan laba berdasarkan modal saham tertentu. Rasio ini merupakan ukuran profitabilitas dari sudut pandang pemegang saham (Hanafi, 2015). Rasio ini menunjukkan daya untuk menghasilkan laba atas investasi berdasarkan nilai buku para pemegang saham. Semakin tinggi rasio ini, semakin baik. Artinya, posisi pemilik perusahaan semakin kuat (Kasmir, 2015). ROE yang tinggi mencerminkan bahwa perusahaan berhasil menghasilkan keuntungan dari modalnya sendiri. Peningkatan ROE akan ikut mendongkrak nilai jual perusahaan yang berimbas pada harga saham, sehingga hal ini berkorelasi dengan peningkatan return saham. Sedangkan apabila ROE rendah, maka mencerminkan perolehan laba bersih perusahaan yang rendah pula. Hal ini berakibat pada saham perusahaan yang kurang diminati oleh investor yang sebagai akibat pembagian dividen yang lebih rendah. Terdapat hubungan yang searah (positif) antara ROE dengan return saham (Aisah \& Mandala, 2016).

\section{Earning per share}

Earning per share merupakan hasil bagi antara laba yang tersedia bagi pemegang saham dengan jumlah rata-rata saham yang beredar (Tandelilin, 2010). Earning per share atau laba per lembar saham merupakan rasio untuk mengukur keberhasilan manajemen dalam mencapai keuntungan bagi pemegang saham (Kasmir, 2015). Apabila EPS perusahaan tinggi akan semakin banyak investor yang mau membeli saham tersebut sehingga menyebabkan harga saham tinggi dan pada akhirnya akan mempengaruhi return saham. Jadi, semakin besar nilai EPS maka semakin besar keuntungan atau returnyang diterima pemegang saham (Hidajat, 2018). 


\section{Pengaruh economic value added terhadap return saham}

Economic value added adalah estimasi laba ekonomis yang sesungguhnya dari perusahaan dalam tahun berjalan. EVA menunjukkan sisa laba setelah semua biaya modal termasuk modal ekuitas dikurangkan (Sasongko dan Shaliza, 2018). EVA positif $(>0)$, menunjukkan bahwa tingkat pengembalian yang dihasilkan lebih besar daripada biaya modalnya atau terdapat nilai ekonomis ke dalam perusahaan selama operasionalnya. Jika EVA $=0$, artinya perusahaan impas karena semua laba digunakan untuk membayar kewajiban kepada investor baik itu kreditur maupun pemegang saham. Jika EVA negatif $(<0)$, menunjukkan bahwa nilai perusahaan berkurang sebagai akibat dari tingkat pengembalian yang dihasilkan lebih rendah dari tingkat pengembalian yang dituntut investor atau kinerja operasional perusahaan gagal memenuhi harapan investor, maka perusahaan tidak membuat nilai tambah karena laba yang tersedia tidak dapat memenuhi harapan penyedia dana terutama pemegang saham (Hidajat, 2018). $\mathrm{H}_{1}$ : economic value added berpengaruh terhadap return saham.

\section{Pengaruh return on equity terhadap return saham}

Return on equity merupakan rasio untuk mengukur laba bersih sesudah pajak dengan modal sendiri. Rasio ini menunjukkan daya untuk menghasilkan laba atas iestasi berdasarkan nilai buku para pemegang saham. Semakin tinggi rasio ini, semakin baik. Artinya, posisi pemilik perusahaan semakin kuat (Kasmir, 2015). ROE yang tinggi mencerminkan bahwa perusahaan berhasil menghasilkan keuntungan dari modalnya sendiri. Peningkatan ROE akan ikut mendongkrak nilai jual perusahaan yang berimbas pada harga saham, sehingga hal ini berkorelasi dengan peningkatan return saham. Sedangkan apabila ROE rendah, maka mencerminkan perolehan laba bersih perusahaan yang rendah pula. Ini berakibat pada saham perusahaan yang kurang diminati oleh investor yang sebagai akibat pembagian dividen yang lebih rendah (Aisah \& Mandala, 2016). $\mathrm{H}_{2}$ : return on equity berpengaruh terhadap return saham.

\section{Pengaruh earning per share terhadap return saham}

Earning per share atau laba per lembar saham merupakan rasio untuk mengukur keberhasilan manajemen dalam mencapai keuntungan bagi pemegang saham. Rasio yang rendah berarti manajemen belum berhasil untuk memuaskan pemegang saham. Sebaliknya dengan rasio yang tinggi, kesejahteraan pemegang saham meningkat. Dengan pengertian lain, tingkat pengembalian yang tinggi. Keuntungan bagi pemegang saham adalah jumlah keuntungan setelah dipotong pajak, keuntungan yang tersedia bagi pemegang saham biasanya adalah jumlah keuntungan dikurangi pajak, deviden dan dikurangi hak-hak lain untuk pemegang saham priorias (Kasmir, 2015). $\mathrm{H}_{3}$ : earning per share berpengaruh terhadap return saham. 


\section{METODE PENELITIAN}

\section{Desain Penelitian}

Penelitian ini menggunakan jenis data kuantitatif. Menurut (Kuncoro, 2013) menyatakan bahwa data kuantitatif merupakan data yang diukur dalam satu skala numerik (angka)dan dapat dibedakan menjadi dua, yaitu data interval (diukur dengan jarak), dan data rasio (diukur dengan proporsi). Dan jenis penelitian ini menggunakan permasalahan asosiatif. Menurut (Kuncoro, 2013) menjelaskan bahwa penelitian asosiatif tidak menjelaskan sebab akibat, melainkan hanya menjelaskan ada atau tidak adanya hubungan variabel yang diteliti.

\section{Operasionalisasi Variabel}

Tabel 1.

Operasionalisasi Variabel

\begin{tabular}{|c|c|c|c|c|}
\hline NO & VARIABEL & INDIKATOR & SKALA & SUMBER \\
\hline 1 & Return Saham & $\frac{\mathrm{P}_{\mathrm{t}}-\mathrm{P}_{\mathrm{t}-1}+\mathrm{D}_{\mathrm{t}}}{\mathrm{P}_{\mathrm{t}-1}}$ & Rasio & (Hartono, 2015) \\
\hline 2 & Economic Value Added & NOPAT - Biaya Modal & Rasio & (Hanafi, 2015) \\
\hline 3 & Return On Equity & $\frac{\text { Laba Bersih Setelah Pajak }}{\text { Total Modal }}$ & Rasio & (Kasmir, 2015) \\
\hline 4 & Earning Per Share & $\frac{\text { Laba Bersih Setelah Pajak }}{\text { Jumlah Saham Beredar }}$ & Rasio & (Kasmir, 2015) \\
\hline
\end{tabular}

\section{Populasi dan Sampel}

Populasi yang digunakan dalam penelitian ini adalah 6 perusahaan sub sektor Kosmetik dan Keperluan Rumah Tangga yang terdaftar pada Bursa Efek Indonesia perioe 2013-2017. Teknik pengambilan sampel menggunakan metode purposive sampling dengan kriteriaperusahaan sub sektor kosmetik dan keperluan rumah tangga yang terdaftar (listing) pada Bursa Efek Indonesia (Bursa Efek Indonesia, 2013-2017). Sehingga didapatkan 4 perusahaan sub sektor kosmetik dan keperluan rumah tangga yang memenuhi kriteria dan digunakan sebagai sampel penelitian.

\section{Metode Pengumpulan Data}

Data yang digunakan dalam penelitian ini merupakan laporan keuangan yang diakses melalui situs resmi Bursa Efek Indonesia (www.idx.co.id, 2018) pada perusahaan sub sektor barang kosmetik dan keperluan rumah tangga.

\section{Teknik Analisis Data}

Metode analisis data dalam penelitian merupakan analisis regresi linear berganda menggunakan software Eviews 10. Adapun tahap analisis regresi data panel sebagai berikut : 


\section{Penentuan Model Estimasi}

Dalam melakukan estimasi model regresi dengan data panel terdapat tiga pendekatan yang sering digunakan, yaitu pendekatan model Common Effect, model Fixed Effect dan model Random Effect (Prasanti, Wuryandari, \& Rusgiyono, 2015).

\section{Common Effect Model (Pooled Regression)}

Common effect model (CEM) yaitu menggabungkan seluruh data tanpa memperdulikan waktu dan tempat penelitian. Pada metode ini mengabaikan heterogenitas antar unit cross-section maupun antar waktu. Ketika mengestimasi parameter common effect model dapat dilakukan dengan ordinary least square (OLS).

2. Fixed Effect Model

Fixed effect model adalah metode regresi yang mengestimasi data panel dengan menambahkan variabel boneka. Dalam FEM setiap individu merupakan parameter yang tidak diketahui dan akan diestimasi dengan menggunakan teknik variabel boneka sehingga metode ini seringkali disebut dengan least square dummy variable model (Rahmadeni \& Murni, 2018).

\section{Random Effect Model}

Pendekatan Random Effect Model (REM) mengasumsikan setiap unit cross section mempunyai perbedaan intersep. Diasumsikan bahwa intersep $\alpha_{\mathrm{i}}$ adalah variabel acak dengan mean $\alpha_{0}$. Sehingga intersep dapat ditulis sebagai $\alpha_{\mathrm{i}}=\alpha_{0}+\varepsilon_{\mathrm{i}}$ dengan $\varepsilon_{\mathrm{i}}$ merupakan error random yang mempunyai mean nol dan varian $\sigma_{\varepsilon}{ }^{2}$. Dengan demikian, metode yang tepat untuk mengestimasi model random effects adalah Generalized Least Squares (GLS) dengan asumsi homokedastik dan tidak ada cross-sectional correlation (Prasanti, Wuryandari, \& Rusgiyono, 2015).

Untuk mengetahui model yang akan digunakan, maka terlebih dahulu dilakukan uji spesifikasi model yang paling baik dan sesuai, terdiri dari uji Chow, uji Hausman dan uji Lagrange Multiplier.

1. Uji Chow

Dilakukannya pengujian uji chow bertujuan untuk mengetahui perbandingan model estimasi yang terbaik antara common effect modelatau fixed effect model untuk digunakan sebagaipenelitian data panel (Prasanti, Wuryandari, \& Rusgiyono, 2015).

Menurut Bangun, dkk (2018) kriteria pengambilan keputusan $(\alpha=$ $0,05)$ yaitu jikap-value chi square $\leq 0,05$ maka $\mathrm{H} 0$ ditolak, sehingga akan menggunakan model fixed effect. Sebaliknya, jika $p$-value chi square $\geq 0,05$ maka H0 diterima, sehingga akan menggunakan model pooled regression(common effect model).Jika hasil yang didapatkan adalah model pooled regression (common effect model) maka akan dilanjutkan ke uji langrange multiplier, dan sebaliknya jika hasil yang didapat adalah model fixed effect maka akan dilanjutkan ke uji Hausman. 
2. Uji Hausman

Hausman testadalah pengujian statistik untuk memilih apakah model Fixed Effect atauRandom Effect yang lebih tepat digunakan dalam regresi data panel.Uji Hausman dilakukan jika dari hasil uji Chow model yang sesuai adalah model fixed effect. Uji Hausman dilakukan untuk memilih model estimasi terbaik antara model fixed effect atau model random effect (Prasanti, Wuryandari, \& Rusgiyono, 2015).

Menurut (Bangun, Dadan, \& Gustyana, 2018) kriteria pengambilan keputusan $(\alpha=0,05)$ yaitu jika nilai prob cross section random $\leq 0,05$ maka H0 ditolak, sehingga akan menggunakan model random effect. Sebaliknya, jika nilai prob cross section random $\geq 0,05$ maka $\mathrm{H} 0$ diterima, sehingga akan menggunakan model fixed effect. Jika hasil yang didapatkan adalah fixed effect maka model yang dipakai dalam regresi data panel adalah model fixed effect dan sebaliknya jika hasil yang didapatkan adalah random effect maka model yang dipakai adalah model random effect.

3. Uji Lagrange Multiplier

Lagrange Multiplier (LM) adalah uji untuk mengetahui apakah model random effect atau model common effect yang lebih tepat digunakan. Uji LM digunakan untuk pengujian random effect yang didasarkan pada nilai residual dari model common effect.Dasar pengambilan keputusanjika nilai Lagrange Multiplier (probabilitas Breusch-Pagan) > 0,05, maka H0 ditolak dan H1 diterima. Sebaliknya, jika nilai Lagrange Multiplier (probabilitas Breusch-Pagan) $<0,05$, maka H0 diterima dan H1 ditolak (Nisa \& Rikumahu, 2018).

\section{Uji Asumsi Klasik}

1. Uji Normalitas

Uji normalitas bertujuan untuk menguji apakah dalam model regresi, variabel pengganggu atau residual mempunyai distribusi data normal atau tidak. Dalam penelitian ini, uji normalitas menggunakan uji Jarque-Bera (Ghozali \& Ratmono, Analisis Multivariat dan Ekonometrika dengan Eviews 10, 2017). Dasar pengambilan keputusan dimana apabila nilai JB > 0,05 maka data terdistribusi secara normal dan sebaliknya apabila nilai JB < 0,05 maka data tidak terdistribusi normal (Dewi, Zusmawati, \& Lova, 2018).

2. Uji Multikolinearitas

Uji multikolinearitas bertujuan untuk menguji apakah dalam model regresi ditemukan adanya korelasi yang tinggi atau sempurna antar variabel independen. Kriteria pengambilan keputusan yaitu jika nilai yang dihasilkan $<0,90$ maka dapat dikatakan tidak adanya multikolinearitas, sebaliknya jika terdapat nilai > 0,90 maka terjadi multikolinearitas (Ghozali \& Ratmono, Analisis Multivariat dan Ekonometrika dengan Eviews 10, 2017). 
3. Uji Heteroskedastisitas

Uji heterokedastisitas bertujuan untuk menguji apakah dalam model regresi terjadi ketidaksamaan variance dari residual satu pengamatan ke pengamatan yang lain.Dalam mendeteksi ada atau tidaknya masalah heteroskedastisitas penelitian ini menggunakan uji Glejser yakni meregresikan nilai mutlaknya dengan variabel independen dan melihat dari nilai probabilitas masing-masing variabel independen nya. Dasar pengambilan keputusan yaitu apabila probabilitas > 0,05 maka $\mathrm{H}_{0}$ diterima, artinya tidak terjadi heteroskedastisitas. Sebaliknya, apabila probabilitas < 0,0.5 maka $\mathrm{H}_{0}$ ditolak, maka dapat disimpulkan terjadi masalah heteroskedastisitas (Ghozali, 2016).

4. Uji Autokorelasi

Uji autokorelasi bertujuan untuk mengetahui ada atau tidaknya autokorelasi pada penelitian maka dapat dilakukan dengan menggunakan uji Durbin-Watson (DW test). Dasar pengambilan keputusan yaitu apabila nilai DW terletak di antara batas atas (dU) dan batas bawah (dL) atau DW terletak antara (4-dU) dan (4-dL), maka hasilnya tidak ada autokorelasi negatif (Ghozali \& Ratmono, 2017).

\section{Analisis Regresi Linear Berganda}

Analisis regresi linear berganda data panel pada penelitian ini bertujuan untuk mengetahui pengaruh dari economic value added, return on equity dan earning per share terhadap return saham pada perusahaan sub sektor kosmetik dan keperluan rumah tangga yang terdaftar di Bursa Efek Indonesia.

\section{Koefisien Determinasi $\left(\mathbf{R}^{2}\right)$}

Koefisien determinasi mengukur seberapa jauh kemampuan model dalam menerangkan variasi variabel dependen.Nilai koefisien determinasi adalah antara nol dan satu. Nilai $R^{2}$ yang kecil berarti kemampuan variabel-variabel independen dalam menjelaskan variasi variabel dependen amat terbatas. Nilai yang mendekati satu berarti variabel-variabel independen memberikan hampir semua informasi yang dibutuhkan untuk memprediksi variasi variabel dependen (Ghozali \& Ratmono, 2017).

\section{Uji Hipotesis}

Uji hipotesis menggunakan uji statistik $\mathrm{t}$ menunjukkan seberapa jauh pengaruh satu variabel independen terhadap variabel dependen dengan menganggap variabel independen lainnya konstan. Dasar pengambilan keputusan $(\alpha=0,05)$ dan $(\mathrm{df}=\mathrm{n}-\mathrm{k})$ yaitu jika $\mathrm{t}_{\text {hitung }}<\mathrm{t}_{\text {tabel}}$, maka $\mathrm{H}_{0}$ diterima dan $\mathrm{H}_{1}$ ditolak artinya variabel independen berpengaruh terhadap variabel dependen. Dan sebaliknya, jika $t_{\text {hitung }}>t_{\text {tabel }}$ maka $\mathrm{H}_{0}$ ditolak dan $\mathrm{H}_{1}$ diterima artinya variabel independen tidak berpengaruh terhadap variabel dependen (Ghozali \& Ratmono, 2017). 


\section{HASIL DAN PEMBAHASAN}

\section{Penentuan Metode Estimasi}

1. Uji Chow (Chow Test)

Tabel 2.

Hasil Uji Chow

\begin{tabular}{lccc}
\hline Effects Test & Statistik & d,f, & Probabilitas \\
\hline Cross-section F & 0,1158 & $(3,13)$ & 0,9492 \\
Cross-section Chi-square & 0,5275 & 3 & 0,9128 \\
\hline \multicolumn{4}{c}{ Sumber : data diolah (2019) }
\end{tabular}

Hasil dari uji chow menunjukkan bahwa nilai prob cross section Chi-Square adalah 0,9128 atau $>0,05$, maka $\mathrm{H}_{0}$ diterima. Oleh karena itu, model yang dipilih adalah common effect. Kemudian pengujian dilanjutkan dengan uji lagrange multiplier.

\section{Uji Lagrange Multiplier}

Berdasarkan hasil dari uji chow menunjukkan model yang dipilih yaitu common effect model.

Tabel 3.

Hasil Uji Lagrange Multiplier

\begin{tabular}{lccc}
\hline Null (no rand. effect) & Cross-section & Period & Both \\
\hline Breusch-Pagan & 2,4346 & 0,0554 & 2,4899 \\
& $(0,1187)$ & $(0,8140)$ & $(0,1146)$ \\
\hline
\end{tabular}

Sumber : data diolah (2019)

Dari hasil uji lagrange multiplier menunjukkan bahwa nilai prob BreuschPagan adalah 0,1187 atau >0,05, maka $\mathrm{H}_{0}$ ditolak. Oleh karena itu, model yang dipilih adalah random effect.

\section{Uji Asumsi Klasik}

1. Uji Normalitas

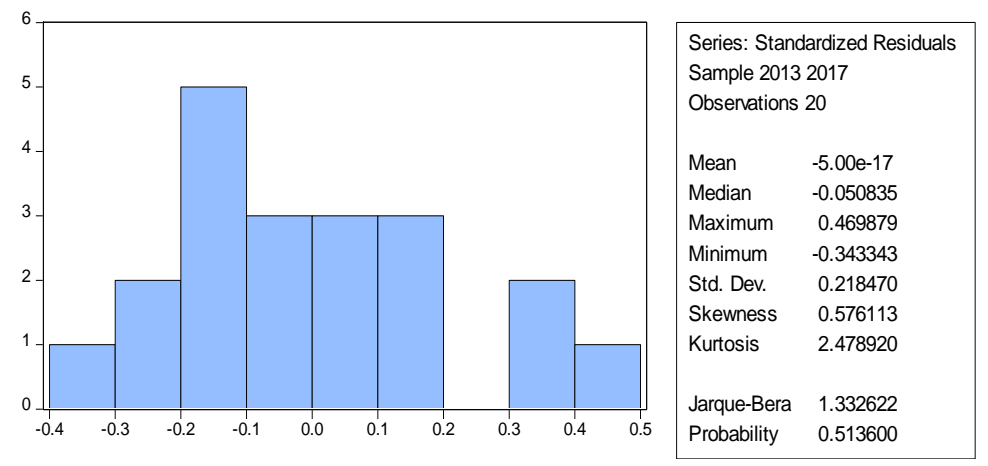

Gambar 1 : Uji Normalitas

Sumber : output eviews 10 (2019)

Hasil menunjukkan nilai probabilitas Jarque-Bera adalah 0,5136 >0,05 maka dapat dikatakan data penelitian ini terdistribusi secara normal. 
2. Uji Multikolinearitas

Tabel 4.

Hasil Uji Multikolinearitas

\begin{tabular}{cccc}
\hline & EVA & ROE & EPS \\
\hline EVA & 1,0000 & $-0,7311$ & $-0,2541$ \\
ROE & $-0,7311$ & 1,0000 & 0,6205 \\
EPS & $-0,2541$ & 0,6205 & 1,0000 \\
\hline \multicolumn{4}{c}{ Sumber: data diolah (2019) }
\end{tabular}

Berdasarkan pengujian terhadap nilai koefisien korelasi, masing-masing variabel mempunyai nilai koefisien $<0,90$, maka dapat disimpulkan bahwa model random effect tidak mengalami masalah multikolinearitas.

3. Uji Heteroskedastisitas

Tabel 5.

Hasil Uji Heteroskedastisitas

\begin{tabular}{ccc}
\hline Variabel & Probabilitas Uji Glejser & Durbin-Watson stat \\
\hline EVA & 0,9178 & - \\
ROE & 0,2601 & - \\
EPS & 0,2739 & - \\
EVA, ROE, EPS & - & 2,7278 \\
\hline
\end{tabular}

Berdasarkan hasil heteroskedastisitasdengan menggunakan uji Glejser menunjukkan hasil probabilitas masing-masing variabel adalah $>0,05$, maka $\mathrm{H}_{0}$ diterima. Dimana nilai probabilitas EVA sebesar 0,9178 >0,05, ROE sebesar $0,2601>0,05$ dan EPS sebesar 0,2739>0,05. Artinya penelitian ini tidak terjadi heteroskedastisitas.

4. Uji Autokorelasi

Hasil uji autokorelasi dapat dilihat melalui random effect yang menghasilkan nilai DW sebesar 2,7278. Jumlah data $(\mathrm{n})=20$ dan $\mathrm{k}=4$. Berdasarkan hasil perhitungan dU dan dL, hasil DW terletak di antara (4-dU) dan (4-dL), maka hasilnya tidak ada autokorelasi negatif.

\section{Analisis Regresi Linear Berganda}

Tabel 6.

Hasil Analisis Regresi Linear Berganda

\begin{tabular}{ccccc}
\hline Variabel & $\begin{array}{c}\text { Koefisie } \\
\mathrm{n}\end{array}$ & t Hitung & Sig, & Adj. R Square \\
\hline C & $-0,1901$ & $-0,5411$ & 0,5959 & - \\
EVA & $-0,0045$ & $-0,2071$ & 0,8386 & - \\
ROE & 0,0687 & 0,3271 & 0,7478 & - \\
EPS & 0,0551 & 1,6552 & 0,1174 & - \\
EVA, ROE, EPS & - & - & - & 0,2635 \\
\hline \multicolumn{5}{c}{ Sumber : data diolah (2019) }
\end{tabular}

Berdasarkan hasil analisis regresi berganda diketahui bahwa: 
1. Nilai konstanta sebesar-0,1901 artinya jika economic value added, return on equity dan earning per share nilainya adalah 0, maka nilai Return Sahamsebesar -0,1901.

2. Variabel $\mathrm{X}_{1}$, economic value added berpengaruh negatif. Dengan nilai koefisien regresi sebesar $-0,005$ yang artinya apabila setiap peningkatan economic value added sebesar 1 satuan, maka akan menurunkan return saham sebesar $-0,005$. Sebaliknya apabila economic value added mengalami penurunan maka akan meningkatkan return saham sebesar -0,005.

3. Variabel $\mathrm{X}_{2}$, return on equity berpengaruh positif. Dengan nilai koefisien regresi sebesar 0,0687 yang artinya apabila setiap peningkatan return on equity sebesar 1 satuan, maka akan meningkatkan return saham sebesar 0,0687 . Sebaliknya apabila return on equity mengalami penurunan maka akan menurunkan return saham sebesar 0,0687.

4. Variabel $\mathrm{X}_{3}$, earning per share berpengaruh positif. Dengan nilai koefisien regresi sebesar 0,055 yang artinya apabila setiap peningkatan earning per share sebesar 1 satuan, maka akan meningkatkan return saham sebesar 0,055 . Sebaliknya apabila earning per share mengalami penurunan maka akan menurunkan return saham sebesar 0,055.

\section{Koefisien Determinasi}

Berdasarkan tabel 3, didapat nilai adjusted $r$-square $\left(\mathrm{R}^{2}\right)$ adalah 0,2635 . Hal ini berarti sebesar 26,35\% variasi return saham dapat dijelaskan oleh variabel bebas economic value added, return on equity dan earning per share. Sedangkan sisanya 73,65\% dijelaskan oleh variabel lain diluar model.

\section{Uji Hipotesis}

Berdasarkan hasil analisis regresi linear berganda menunjukkan hasil $t_{\text {hitung }}$ untuk variabel independen economic value added $\left(\mathrm{X}_{1}\right)$ sebesar $-0,2071$, sementara nilai $\mathrm{t}_{\text {tabel }}$ dengan $\alpha=0,05 \mathrm{dan} \mathrm{df}=(\mathrm{n}-\mathrm{k}), \mathrm{df}=16$ dimana nilai $\mathrm{t}_{\text {tabel }}$ adalah sebesar 1,74588 yang berarti bahwa nilai t-hitung lebih kecil daripada nilai $t_{\text {tabel }}$ yaitu $0,2071<1,74588$. Hal tersebut dapat diartikan bahwa economic value added berpengaruh tidak signifikan terhadap return saham.

Selanjutnya untuk variabel return on equity $\left(\mathrm{X}_{2}\right)$ menunjukkan hasil $\mathrm{t}_{\text {hitung }}$ sebesar 0,3271 . Sementara nilai $\mathrm{t}_{\text {tabel }}$ sebesar 1,74588 yang artinya nilai $\mathrm{t}_{\text {hitung }}$ lebih kecil daripada $t_{\text {tabel }}$ yaitu $0,3271<1,74588$. Artinya return on equity berpengaruh tidak signifikan terhadap return saham.

Kemudian untuk variabel earning per share $\left(\mathrm{X}_{3}\right)$ menunjukkan hasil $\mathrm{t}_{\text {hitung }}$ sebesar 1,6552. Sementara nilai $t_{\text {tabel }}$ sebesar 1,74588 yang berarti nilai $t_{\text {hitung }}$ lebih kecil daripada $t_{\text {tabel }}$ yaitu $1,6552<1,74588$. Artinya earning per share berpengaruh tidak signifikan terhadap return saham. 


\section{Pembahasan}

1. Pengaruh economic value added terhadap return saham

Berdasarkan analisis regresi yang telah dilakukan pada variabel economic value added terhadap return saham menunjukkan nilai signifikan sebesar 0,005. Kemudian dari uji $\mathrm{t}$ parsial menunjukkan hasil $\mathrm{t}_{\text {hitung }}$ lebih kecil daripada $\mathrm{t}_{\text {tabel }}$ yaitu $-0,2071<1,74588$ dan nilai probabilitas sebesar $0,8386>$ 0,05. Maka hipotesis pertama yang menyatakan bahwa economic value added berpengaruh terhadap return saham, ditolak. Artinya bahwa economic value added berpengaruh tidak signifikan dengan arah negatif terhadap return saham. Hasil penelitian ini didukung oleh penelitian (Sudiyatno \& Suharmanto, 2011) dan penelitian (Sasongko \& Shaliza, 2018) yang menyatakan bahwa economic value added berpengaruh tidak signifikan terhadap return saham.

2. Pengaruh return on equity terhadap return saham

Berdasarkan analisis regresi yang telah dilakukanpada variabel return on equity terhadap return saham menunjukkan nilai signifikan sebesar 0,069. Kemudian dari uji t parsial menunjukkan hasil t-hitung lebih kecil daripada $\mathrm{t}_{\text {tabel }}$ yaitu $0,3271<1,74588$ dan nilai probabilitas sebesar $0,7478>0,05$. Maka hipotesis kedua yang menyatakan bahwa return on equity berpengaruh terhadap return saham, ditolak. Artinya bahwa return on equity berpengaruh tidak signifikan dengan arah positif terhadap return saham. Hasil penelitian ini didukung oleh penelitian (Legiman, Tommy, \& Untu, 2015) dan penelitian (Aisah \& Mandala, 2016) yang menyatakan bahwa return on equity berpengaruh tidak signifikan terhadap return saham.

3. Pengaruh earning per share terhadap return saham

Berdasarkan analisis regresi yang telah dilakukan pada variabel earning per share terhadap return saham menunjukkan nilai signifikan sebesar 0,055. Kemudian dari uji $t$ parsial menunjukkan hasil $t_{\text {hitung }}$ lebih kecil daripada $t_{\text {tabel }}$ yaitu $1,655209<1,74588$ dan nilai probabilitas sebesar $0,1174>0,05$. Maka hipotesis ketiga yang menyatakan bahwa earning per share terhadap return saham, ditolak. Artinya bahwa earning per share berpengaruh tidak signifikan dengan arah positif terhadap return saham. Hasil penelitian ini didukung oleh penelitian (Himmatussuhra, Mardani, \& ABS, 2018) dan penelitian (Arista, 2012) yang menyatakan bahwa earning per share berpengaruh tidak signifikan terhadap return saham.

\section{E. SIMPULAN} berikut:

Berdasarkan hasil penelitian maka dapat diambil kesimpulan sebagai

1. Economic value added berpengaruh negatif dan tidak signifikan terhadap return saham.

2. Return on equity berpengaruh positif dan tidak signifikan terhadap return saham. 
Z. Ramadhan; D. Aulia / Journal of Applied Business and Economics (JABE) Vol. 6 No. 1 (September 2019) 54-69

3. Earning per share berpengaruh positif dan tidak signifikan terhadap return saham. 


\section{DAFTAR PUSTAKA}

Agusyanti. (2018). Harga Barang Yang Berpotensi Naik Akibat Rupiah Melemah. Retrieved Oktober 15, 2018, from https://m.cnnindonesia.com/ekonomi/2018090417348-92-327583/hargabarang-yang-berpotensi-naik-akibat-rupiah-melemah

Aisah, A. N., \& Mandala, K. (2016). Pengaruh Return On Equity, Earning Per Share, Firm Size dan Operating Cash Flow terhadap Return Saham. EJurnal Manajemen Unud, Vol. 5, No. 11 .

Arista, D. (2012). Analisis Faktor-faktor yang mempengaurhi return saham (studi kasus pada perusahaan manufaktur yang go public di bei periode tahun 2005-2009). Jurnal Ilmu Manajemen dan Akuntansi Terapan, Vol. 3, No. 1 .

Atidhira, A. T., \& Yustina, A. I. (2017). The Influence of Return on Asset, Debt to Equity Ratio, Earnings per Share, and Company Size on Share Return in Property and Real Estate Companies. JAAF (Journal of Applied Accounting and Finance), Vol.1, No.2, Page. 128-14.

Awan, A. G., Siddique, K., \& Sarwar, G. (2014). The Effect Of Economic Value Added On Stock Return: Evidence From Selected Companies Of Karachi Stock Exchange. Research Journal of Finance and Accounting, Vol.5, No.23, Page. 140-152.

Bangun, N. J., Dadan, R., \& Gustyana, T. T. (2018). Analisis Pengaruh Kesehatan Bank Menggunakan Metode Risk Based Bank Rating Terhadap Harga Saham Pada Sektor Perbankan Yang Listing Di Bursa Efek Indonesia Periode 2012-2016. E-Proceeding Of Management, Vol.5, No.2 .

Bursa Efek Indonesia. (2013-2017). Laporan Keuangan Periode 2013-2017. Jakarta: Bursa Efek Indonesia.

Dewi, A. S., Zusmawati, \& Lova, N. H. (2018). nalisis Kinerja Keuangan dan Ukuran Perusahaan Terhadap Harga Saham Perusahaan dalam Indeks LQ45 Di BEI dengan Regresi Data Pane. Jurnal Pundi, Vol.2, No.2 .

Ghozali, I. (2016). Aplikasi Analisis Multivariate dengan Program IBM SPSS 23. In I. Ghozali, Aplikasi Analisis Multivariate dengan Program IBM SPSS 23. Semarang: Badan Penerbit Universitas Diponegor.

Ghozali, I. (2016). Aplikasi Analisis Multivariate dengan Program IBM SPSS 23. Semarang: Badan Penerbit Universitas Diponegoro.

Ghozali, I. (2016). Aplikasi Analisis Multivariate dengan Program IBM SPSS 23. Semarang: BPFE Universitas Diponegoro.

Ghozali, I. (2016). plikasi Analisis Multivariate dengan Program IBM SPSS 23. Semarang: Badan Penerbit Universitas Diponegoro.

Ghozali, I. (2016). plikasi Analisis Multivariate dengan Program IBM SPSS 23. Semarang: BPFE Universitas Diponegoro. 
Ghozali, I., \& Ratmono, D. (2017). Analisis Multivariat dan Ekonometrika dengan Eviews 10. Semarang: Badan Penerbit Universitas Diponegoro.

Hanafi, M. M. (2015). Manajemen Keuangan. Yogyakarta: BPFE.

Hartono, J. (2015). Teori Portofolio dan Analisis Investasi Edisi Kesepuluh. Yogyakarta: BPFE.

Hidajat, N. C. (2018). Pengaruh Return On Equity, Earnings Per Share, Economic Value Added, dan Market Value Added Terhadap Return Saham Perusahaan Sektor Pertanian Yang Terdaftar Di Bursa Efek Indonesia Periode 20102016. Jurnal Ekonomi, Vol. 23 No. 01 .

Himmatussuhra, Mardani, M. R., \& ABS, M. K. (2018). Pengaruh EPS, ROE, DER dan TATO Terhadap Return Saham Pada Perusahaan Perbankan Yang Terdaftar di BEI. E-Jurnal Riset Manajemen UNISMA .

Kasmir. (2015). Analisis Laporan Keuangan. Jakarta: Raja Grafindo Persada.

Kuncoro, M. (2013). etode Riset Untuk Bisnis \& Ekonomi, Bagaimana Meneliti dan Menulis Tesis? Edisi Keempat. Jakarta: Erlangga.

Kusuma, R. A., \& Topowijono. (2018). Pengaruh Economic Value Added dan Market Value Added (MVA) Terhadap Return Saham (Studi pada Perusahaan yang Terdaftar dalam Indeks LQ45 di Bursa Efek Indonesia Periode 2012-2016). Jurnal Administrasi Bisnis, Vol. 61 No. 3 , Hal. 65-72.

Legiman, F. M., Tommy, P., \& Untu, V. (2015). aktor-faktor yang mempengaruhi return saham pada perusahaan agroindustry yang terdaftar di Bursa Efek Indonesia periode 2009-2012. Jurnal EMBA : Jurnal Riset Ekonomi, Manajemen, Bisnis Dan Akuntansi, Vol. 3 No. 3 , Hal. 382-392.

Montoliang, F. C., \& Tjun, T. L. (2018). Pengaruh Free Cash Flow dan Economic Value Added Terhadap Return Saham (Studi pada Saham Perusahaan yang Tercatat Aktif dalam LQ 45 di BEI Periode 2015-2017. Jurnal Akuntansi Maranatha, Vol. 10 No. 2 .

Nisa, A. K., \& Rikumahu, B. (2018). Pengaruh Bid-Ask Spread Terhadap Return Saham Pada Indeks Saham LQ45 Yang Tercatat Di Bursa Efek Indonesia (BEI) Periode 2012-2016. E-Proceeding Of Management, Vol.5, No.1 .

Prasanti, T. A., Wuryandari, T., \& Rusgiyono, A. (2015). Aplikasi Regresi Data Panel Untuk Pemodelan Tingkat Pengangguran Terbuka Kabupaten/Kota Di Provinsi Jawa Tengah. Jurnal Gaussian, Vol.4, No.3 , Hal. 687-697.

Rahmadeni, \& Murni, S. (2018). Analisis Pengaruh Inflation, Exports, dan Exchange Rate Terhadap Gross Domestic Product di Asean-5 dengan Menggunakan Data Panel. Jurnal Sains Matematika dan Statistika, Vol.4, No.1 .

Rahmawati, W. T. (2018). Bisnis Kosmetik Lesu Martina Berto Mergui Rp 21 Miliar. $\quad$ Retrieved $\quad$ Oktober 15, 2018, from 
https://investasi.kontan.co.id/news/bisnis-kosmetik-lesu-martina-bertomerugi-rp-21-miliar

Saragih, J. L. (2018). The Effects of Return on Assets (ROA), Return on Equity (ROE), and Debt to Equity Ratio (DER) on Stock Returns in Wholesale and Retail Trade Companies Listed in Indonesia Stock Exchange. International Journal of Science and Research Methodology, Vol. 8, No.3, Page. 348-367.

Sasongko, H., \& Shaliza, F. (2018). engaruh Leverage, Profitabilitas, dan EVA Terhadap Return Saham Pada Industri Makanan Dan Minuman Yang Terdaftar Di Bei Tahun 2012-2016. Jurnal Ilmiah Akuntansi Fakultas Ekonomi, Vol. 4 No. 1 , Hal. 51-64.

Sudarsono, B., \& Sudiyatno, B. (2016). Faktor-Faktor Yang Mempengaruhi Return Saham Pada Perusahaan Property Dan Real Estate Yang Terdaftar Pada Bursa Efek Indonesia Tahun 2009-2014. Jurnal Bisnis dan Ekonomi Vol. 23 No. 1 , Hal. 30-51.

Sudiyatno, B., \& Suharmanto, T. (2011). Kinerja Keuangan Konvensional, Economic Value Added, dan Return Saham. Jurnal Dinamika Manajemen, Vol. 2 No. 2 , Hal. 155-161.

Tandelilin, E. (2010). Analisis Investasi dan Manajemen Portfolio. Yogyakarta: Kanisius.

www.idx.co.id. (2018). Retrieved November 25, 2018, from https://www.idx.co.id. 